\title{
How to Say 'Road' in Irish: \\ Towards Determining a Semantic Derivation of Item \#67 \\ (68) from the Swadesh List (Continental and Insular \\ Celtic)
}

Tatyana A. Mikhailova

\section{Introduction}

In a talk given at a session of the Nostratic Seminar the day before his death, Sergej Starostin presented his intriguing calculations of stability levels for the basic Swadesh vocabulary list ${ }^{1}$ (his paper would be published posthumously; see Starostin 2007). His work includes a comparative table of stability for each basic word of the 110-word lists for 14 language families, and then hierarchical lists within these families, which are themselves of great interest for analysis. Words of a low stability index seemingly must belong to the realms of culture, religion and spirituality and be linked to the history of what is conventionally called civilisation. Conversely, the words for two, I, we, all, who, etc. are expected to have high indexes of stability, simply because there are no inherent reasons for their replacement. These considerations are partly true for Indo-European (IE) languages, for which the most stable word is two and the least stable is fat. The same tendency is, to a certain extent, seen in Dravidian, Khoisan and Pama-Nyungan; yet, in Austronesian, for instance, the most stable word is the one for louse, and in Thai languages water, rain and fire.

However, it is worth noting that the variation of stability indexes between language families may stem not just from the culturally specific ways of thinking, but also from their date of divergence. As Starostin wrote, "The stability index depends on how much time has passed since the branching of the proto-language of a given family. Thus, if for Slavic languages the stability index for the words meaning 'bark' is 1, for Balto-Slavic it [is] 0.81, and for IE only 0.27" (Starostin 2007: 828). This implies, as far as I understand, that relatively "young" language families are expected to have generally high levels of lexical stability, and this is confirmed by Starostin's own calculations. But the tendency towards perpetual replacement and displacement of the words regarded as "basic" is, anyway, invariable, and for any language it appears to be somewhat indispensable; without it, a language ceases to evolve and dies.

1. See Swadesh 1952, 1955; on revision of the method, Starostin 1999; Blažek 2007; Starostin 2010; for the sceptical approach, Mallory 2013: 258; Dolgopolsky 2000; on glottochronology and Celtic languages, Fowkes 1971; Elsie 1979; Blažek and Novotna 2006; Parina 2009; the item numeration is according to Fowkes 1971 and Kassian et al. 2010. 


\subsection{What is "basic" meaning?}

The proponents of the use of lexicostatistical data for pinpointing the age of language family branching, as well as for genetic classification of scarcely attested and/or described languages, are unaware, it seems to me, that the very work they are doing - that is, making etymologised and relatively well-dated lists - is of much value for studying regular semantic shifts. ${ }^{2}$ Firstly, one issue that can be raised is the reason why this or that word has lost its original semantic core or base meaning (which does not necessarily mean the overall loss of its cognates in this language). Secondly, the original semantics of the words that adopted a common or base meaning thus replacing another more specific word that was lost for either cultural or religious reasons may provide material for further comparative research.

A simple example may be given. One need not study the history of Romance languages in detail to identify that social and religious changes resulted in their loss of the reflexes of Proto-Indo-European (PIE) *egnis/ognis 'fire' (IEW 293), which stood rather for "sacred fire", related to the pagan pantheons and bearing religious meaning, so that in nearly all Romance dialects it was superseded by the reflexes of Latin focus 'hearth' (cf. Fr. feu, Old Fr. fou 'fire; hearth; family; home' (Greimas 1968: 285), It. fuoco, Sp. fuego, Rom. foc, Port. fogo ${ }^{3}$ ). The data from 56 Romance languages and dialects attest to not a single exclusion; however the stability index of 'fire' for IE in general, according to Starostin, is only 0.29. Curiously, the same replacement has happened in Celtic, which has also lost the reflexes of the IE stem for 'fire', superseded by the words related to the idea of "warm, heating; hearth, home": cf. Old Irish tene, Middle Welsh tan, Breton tan, Cornish tan, all bearing the basic meaning of "fire as a source of heat".

Matasović (2009: 375) postulates that the said semantic shift had already happened in Proto-Celtic, and reconstructs the proto-form as *tefnet (derived from IE *tep- 'to be warm', IEW 1070); yet to my mind, it does not seem to be true. I would be more inclined to suggest that this semantic shift took place in Goidelic and Brittonic branches independently, during the emergence of the so-called "Insular Celtic Sprachbund"; moreover, the Brittonic vocalism suggests another grade of the root, which may be linked to Gaulish evidence overlooked by Matasović (for a more detailed analysis, see Wodtko et al. 2008: 699-700).

But let us return to the idea of 'road'. Justifying one's choice of a certain word as "basic", to fit it into the 100-word list, from multiple attested synonyms, may be problematic. As a kind of test context, I have, in a number of cases, resorted to translations of Mark 10: 46:

2. For the "regular or recursive" semantic shift, see Zalisniak et al. 2012.

3. For the Romance dialectal database, see The Tower of Babel website http://starling.rinet.ru/cgibin/ [last accessed 10.11.2019]. 
Bartimaeus the son of Timaeus, a blind beggar, was sitting by the road.

Compare this to Matthew 7:14:

How narrow is the gate and difficult the way that leads to life ${ }^{4}$

This example was taken by me from the Germanic languages section of the Tower of Babel database. This example is very good, on the one hand, because it specifically refers to 'road' as a basic idea, namely, a locus of movement. On the other hand, the semantic distinction present in both modern Russian (doroga - put') and English (road - way) is absent in a number of languages, especially earlier ones: the Greek original has óó́ in both contexts, Latin has via and Old Church Slavonic has put'. All the more interesting are the cases in which the translation has different words in the two passages.

In the seminal work by Kassian et al. (2010), aimed at a clarification of the semantics of the word tentatively seen as "basic", the authors notice that, when performing fieldwork and collecting linguistic materials, one should present to the informants simpler contexts, like "he is walking along the road" or "there is a road from my village to the neighbouring one", and "in many cultures 'footpath' is the correct equivalent (since 'road' may be taken to represent a cultural term imposed by a technologically superior civilization)" (Kassian et al. 2010: 73). If I understand it correctly, this would be an equivalent of using the Russian word shosse ('motorway') rather than the mere doroga ('road'). Indeed, what may be perceived by an anthropologist as a footpath in the wilderness rather than 'road' may, to the locals, be exactly "the most typical kind of walking", co-existing with another type of locus of movement related to a different type of civilisation - both technically and lexically, since the borrowed cultural notion typically comes with a corresponding loanword. Moreover, the distinction noted by the authors seems to be relevant for specific regions still somewhat outside modern civilisation. My task is rather to identify derivative models of the words for 'road' in languages of relatively recent development, reflecting to some extent a European worldview and sharing the same, quite civilised "picture of the world". So, to me, searching for 'footpaths' in Danish, German, Italian and even Old Irish or Gothic makes little sense.

In a number of cases, as noted above, identifying the truly "basic" (that is, most neutral) equivalent for a Swadesh word may present a range of difficulties. Thus, on the one hand, it is not always possible to pinpoint diachronically the moment when

4. See: https//www.biblegateway.new_english_translation.com [last accessed 04.09.2019]. Let me point out that this can also be interpreted in a secondary sense, following the metaphorical development of the word in modern English meaning the 'means,' i.e. 'mode of behaviour'. I will return to this later in the article. 
this or that word within the same semantic field receives the status of "basic". On the other hand, even at the synchronic level, it is not necessarily obvious - even for native speakers of the language - which specific words among multiple close synonyms are "basic" or not. ${ }^{5}$ As a possible test, albeit one of tentative and preliminary character, I would suggest the extent of elaboration of metaphoric and idiomatic usage of each word, which may be an indicator of how deeply it is rooted in a given language's "picture of the world" at each synchronic level. However, this is still open to debate, and the solution often depends on the researchers' subjective choice.

\subsection{Models of semantic shift: A general approach}

I see the primary task to be identifying a limited number of semantic derivative models, which would apply to a variety of languages, and then applying these models to the distribution map of Celtic languages. In this, I partly follow Blažek (2010), who published a book on designations of "blacksmith" in IE languages. He examined and etymologised 50 lexemes, which he divided into eight subgroups, after eight models of periphrastic description of "blacksmith" as 'worker', 'master', 'striker', 'hammer striker', 'fire-maker', etc. (Blažek 2010: 79-80). A common PIE term for "blacksmith", naturally, cannot be reconstructed, since metalwork is of relatively recent origin, so the words for "blacksmith" emerged after the divergence of common PIE, each time independently. 'Road' is quite different in this respect. In my brief research work, I do not claim to have covered all the IE data, or even to have given any extensive coverage to Celtic, but I will present a number of cases, which are representative, to illustrate the models of semantic derivation I have identified, seeking to boil down the number of these models to a minimum.

So, as a preliminary conclusion, partly based on my earlier observations and comparison, I am able to define and single out just three active semantic models for 'road':

(1) The general idea of moving or walking;

(2) The specification of making the road;

(3) The idea of a preferential user of the road or a preferential mode of using it.

Each of the models needs more illustrations and commentary. Besides, some languages have a clear tendency towards consistent replacement of the words formed after Model 1 by the words formed after Models 2 and 3; other languages still unexpectedly preserve Model 1.

5. See its definition as "the most general meaning” suggested in Dočkalová and Blažek (2011: 299). 


\subsection{Model 1}

Model 1 was outlined or formulated in The Oxford Introduction to Proto-Indo-European and the Proto-Indo-European World by Mallory and Adams. According to the authors, "most words for 'path' or 'road' tend to be transparent derivations from verbal forms [of] 'go'” (Mallory and Adams 2006: 250). ${ }^{6}$ Dočkalová and Blažek (2011) arrived at the same (quite obvious) conclusion. In their summarising work On Indo-European Roads, they write that "it is obvious, but not surprising that the most productive source for names of 'path, road' and related notions is verbs of movement" (Dočkalová and Blažek 2011: 329). To my understanding, this means a regular semantic shift of metonymic nature: movement as a modus transforms into a locus marking this movement. Namely, there is first specification of the process, isolation of one of its parts and then establishment of a local component with the meaning of 'setting' in the language. This metonymic substitution is a characteristic of semantic shifts in general (see Traugott and Dasher 2002: 27-8). In parallel, in some cases, nominalisation of the verbal stem takes place, causing certain morpho-phonetical changes in it.

This semantic shift is one of the multiple and productive types of polysemy, which the Russian linguist Apresian (1995, I: 199) defined as "action => setting of the action”. Apresian's definition of semantic shift belongs, as far as I understand, to the realm of synchronic semantics, while my task is to demonstrate that basically the same mechanisms of transfer operate at the level of diachronic derivation.

Multiple examples can be cited, yet a question still arises: can all of the reconstructed PIE words given in the above-mentioned work by Mallory and Adams (and also in their more extensive list of PIE stems in Mallory and Adams 1997: 487-8; cf. also Buck 1949: 717-9) actually be designations of 'road' in the narrower sense as "a strip of land intended for travel"? And if, in a daughter language, one of the said stems bears this meaning, is it an archaic trait or, conversely, an innovation that gave the word for 'path, passage' the newer meaning of 'road'?

Among the "road terms", Benveniste studied the PIE verbal stem *pent-,

Tel est, par exemple, le cas du nom du 'chemin': skr. pánthäh, av. pantằ, arm. hun, v.sl. pọtĭ, v.pr. pintis, gr. póntos, lat. pons. L'antiquité indo-européenne du terme est garantie par les archaïsmes de la flexion. On ne saurait dire que le sens fasse obstacle à la restitution d'une forme commune. Néanmoins les divergences apparaissent assez serieuses pour justifier une question. En indo-iranien, slave et baltique, il s'agit du 'chemin'. Mais gr. póntos signifie 'mer'; lat. pons designe le 'pont', et arm. hun, le 'gue'.

(Benveniste 1954: 256)

6. See also the suggested original verbal meaning 'gehen hinaus, herangekommen' in LIV (470).

7. But see also pontifex, a chief high priest in Rome, as 'bridge/way maker', the one who smoothed the bridge between gods and men (see Schrijver 1991: 372; De Vaan 2008: 480). 
Such, for instance, is the case of the term for "road": Sans. panthäh, Av. pantằ, Arm. hun, O.Slav. pơtĭ, O.Pr. pintis, Gr. póntos, Lat. pons. The Indo-European antiquity of the terms is guaranteed by the archaisms in the inflection. We cannot say that the meaning raises an obstacle to the reconstruction of a common form. Nevertheless the divergences appear serious enough to justify an examination. The Indo-Iranian, Slavic, and Baltic words mean 'road.' But Gr. póntos signifies 'sea'; Lat. pons designates 'bridge,' and Arm. hun 'ford'.

(Benveniste 1973: 255)

From the usage of the Vedic panthās, which meant not just 'motion' from one place to another, but that "associated with hardships, uncertainty and danger", Benveniste infers that the original meaning of the root was 'overcoming' (franchissement):

Le pánthāh n'est donc pas tracé à l'avance ni foulé regulierement. C'est bien plutôt un franchissement' tenté à travers une région inconnue et souvent hostile, une voie ouverte par les dieux à la ruée des eaux, une traversée d'obstacles naturels, ou la route qu'inventent les oiseaux dans l'espace, somme toute un chemin dans une région interdite au parcours normal, un moyen de parcourir une étendue perilleuse ou accidenée. L'equivalent le plus approche sera plutot 'franchissement' que 'chemin', et c'est bien ce sens qui explique la diversité des variantes attestées.

(Benveniste 1954: 257)

The pánthāh is thus neither plotted in advance nor regularly trod. It is indeed rather a 'crossing' attempted over an unknown and often hostile region, a path opened by the gods to the onrush of waters, a passage past natural obstacles, or the route that birds invent in space; in short, a way into a region forbidden to normal passage, a means of going through a perilous or uneven expanse. The closest equivalent would be 'crossing' rather than 'road' and it is indeed this sense which explains the diversity of the documented variants.

(Benveniste 1973: 256)

In my opinion, this idea is also supported by the data from Germanic languages, ${ }^{8}$ in which derivatives of the PIE word retain a verbal nature: cf. OHD. fandon 'to track', Eng. find, ON. finna 'to find (out), to feel, to perceive' (see De Vries 1962: 120).

In Slavic languages, the reflexes of the PIE *pent-, rather than 'road', have instead the meaning of 'way', that is, "direction of passage; figuratively - way of

8. The Common Proto-Germanic (?) * pað-, from which the English path and many other Germanic cognates of similar meaning derive, may be a loanword from some branch of Iranian (see Orel 2003: 291); as Watkins suggested (2011: 67), it was borrowed from Scythian migrants. Kroonen (2013: 396) gives the Proto-Germanic form as * $p a p a^{-}$, retaining the idea of a possible early borrowing. 
doing something, method"; there are also some curious peculiar cases, like Lower Sorbian puś, Czech pout' 'pilgrimage' (Dočkalová and Blažek 2011: 304). However, this tendency does not include the south Slavic area, where the derivatives of the same IE word typically retain the meaning of 'road', or, rather, do not make any distinction between 'road' and 'way'. Cf. Serbian put 'way, road' (however, Croatian distinguishes between cesta 'road' and put 'way'), and Bulgarian put 'way, road' (for more detail, see Derksen 2008: 417). Can this phenomenon qualify as preservation of the more archaic word thus attributing to it a "new" notion describing directional motion? The answer may be positive (cf. the absence of distinction between 'way' and 'road' in Old Church Slavonic mentioned above). A similar type of conflation of the two is observable in Germanic languages, for which the reconstructed archaic proto-word is *wegaz, whose cognates retain the basic meaning of 'road' in some of the modern languages (Swedish vägen, Icelandic vegur, Danish vejen, Norwegian veien, etc.). See a similar lack of distinction between 'road' and 'way' in Gothic where wigs stood for both: ${ }^{9}$

\section{Mark 10.46-sunus Teimaiaus, Barteimaius blinda, sat faur wig duaithron ${ }^{10}$ \\ Blind Bartimaeus, the son of Timaeus, was sitting by the roadside ${ }^{11}$ begging \\ Matthew 7.14- hvan aggwu pata daur jah praihans wigs sa brigganda in libaini \\ Because strait is the gate and narrow is the way, which leaded unto life.}

However, it is worth remembering that the Greek original has also the same word in both fragments, $\delta \delta o ́ s$, and therefore the use of nuanced synonyms in later translations is a kind of semantic innovation introduced by later translators, creative speakers of the languages in which the clear distinction between a physical 'road' and a metaphorical 'way (to heaven)' already existed.

Yet to me, another point is of more importance: can we tell for sure that a certain stage of early semantic evolution would always see the emergence of a word with a generic meaning of 'way/road' (and most typically, based on a verbal stem meaning 'motion'), which is then, rather than being displaced by the language,

9. Also derived from the PIE root with a generic meaning of motion - * weg' $h$ - (IEW: 1120). Contrary to what is stated in Ernout-Meillet (1939: 1101), this is unrelated to the Latin via 'road, way' (from PIE *wei- 'gehen, ersehnen, wollen,' IEW: 1123).

10. See www.wulfila.be/gothic/browse/ [last accessed 03.01.2020].

11. The English translation of these Gospel quotations, given by me, is somewhat artificial, since each existing translation of the Scriptures is both the translator's interpretation and a cross-section of linguistic and cultural milieu, representing the characteristics of the language when it was written. The King James Bible has highway in this verse, which demonstrates a relatively late establishment of the word road as basic in English. 
supplied by a new notion of 'road as space specifically intended for moving', now formed after a different model (see below)? Whether the answer is positive is not as obvious as it may at first appear to be.

I will illustrate my idea with a simple example from modern Russian. The word perehod 'passage' in Russian may mean either: 1. 'act of spatial transition from point A to point B; crossing'; 2. Metaphorically, 'any transition within one's lifespan, such as change of status', for instance obryad perehoda 'rite of passage'; 3. metonymically, a place allocated for meaning 1 , such as podzemnyi perehod 'underpass', or perehod as a generic term for any marked pedestrian crossing. Meanings 1 and 3 can easily coexist in the same sentence by the same speaker, and their semantic nuancing is defined contextually. ${ }^{12}$ This is an example invented by myself:

Perehodit' ulitsu nado tol'ko po perehodu, perehod ulitsy $v$ drugom meste opasen $i$ dlya peshehoda, i dlya voditelya.

One should cross the road at the pedestrian crossing only, crossing the road elsewhere is dangerous for both the pedestrian and the driver. (my emphasis)

In Celtic, the derivatives of PIE *pent- lost the semantic of movement and locus of movement, but, to my understanding, put the emphasis upon the destination of this movement. Thus, from the PIE stem *pent- the Old Irish áit 'place' is tentatively derived, and this has no parallels in Brittonic (LEIA-A: 52). This etymology was challenged in by Matasović (2009: 433) as vocalically inaccurate and semantically questionable. This is still open to debate, however; in any case, the supposed Common Celtic 'road' must run somewhere else.

\subsection{Model 1 in Celtic}

The PIE stem with the meaning of 'road, way, passage' that has got reflexes in Celtic is assumed to be the verbal stem * sent- 'to go, to find the way', with provenance mostly in the north-west area (Italic, Germanic and Celtic languages). Curiously, Pokorny distinguishes between the two meanings of the PIE root, "spiritual" (geistig) and "own, original" (eigentlich), without commenting upon the relationship between them (IEW: 908). Indeed, at first sight, the notions of 'walking, motion' (reflected in OEng. sio 'way, destiny', 13 ON sinni 'way, travel', OHG. sind 'way, travel') and 'thought, feeling' (Lat. sentire 'to feel', MHG. sin 'mind, thought', Lit. sintéti 'to think')

12. For meaning 3, modern Russian also employs the traffic term zebra (from the resemblance of the animal colour pattern to the pedestrian crossing). But does this mean we could actually use the word zebra for any transition, such as getting through a mountain pass or change of social status? Definitely not-at least, not in this specific case.

13. See Smirnitskaja (2008). 
seem totally unrelated. Yet the comparison with the above-cited ON. finna 'to find, to feel, to perceive sensually' (from PIE * pent 'to walk, to move with effort') allows in this case to deduce the logical, if not productive, direction of semantic derivation: 'to walk' => 'to find the way' => 'to perceive, to think' (I believe that this subject requires further investigation).$^{14}$

Celtic languages retained the PIE root only in its "original" meaning of 'walking' or 'moving', but it received later a variety of semantic nominative derivations, especially in Goidelic.

The semantic of derivatives of * sentu- in Continental Celtic is not quite clear. Cognates are preserved in some Gaulish and British place names (quite far away from each other), in ethnonyms and even in proper names (see Falileyev 2010: 30). Cf. the place name Gabro-senti 'goat trail' in Britain, Sento-latis 'road of heroes' in France (department Isère, south-east), and Sintoion, a Galatian fort in today's Armenia (Delamarre 2003: 271). In Gallia Narbonensis, an ethnonym Sentii is attested, meaning possibly 'those who live by the road' or 'those who control the road' (De Hoz 2005: 178). An interesting derivative was noticed by Delamarre, who correctly recognised in the proper name Cosintus the meaning of 'fellow-traveller' (Delamarre 2005: 48). That is, at least some semantic link with the idea of "passing" or "moving" is visibly demonstrated, yet there is still not enough evidence that any of these Gaulish words had the status of "basic". Moreover, in his dictionary, Delamarre supposed that the generic 'road' in Gaulish would have rather been the reconstructed stem *cammano-, whose reflex in Medieval Latin was the loanword camminus (from which MFr. chemin 'road' is derived). This is also derived from a PIE stem with a generic meaning of 'walking' - *king- (LEIA-C: 55).

In Breton, the Common Celtic *sentu- is strikingly stable and shows a broad variety of meanings. Thus, Breton hent is, according to dictionaries, almost the only equivalent for French words route, chemin, voie; the noun hentez 'neighbour, friend' (presumably from 'fellow-traveller') is derived from the same word through suffixation. See a lack of distinction between 'road' and 'way' in our test-examples:

Matthew 7.14: Rag eñk eo an nor, ha striz an hent a gas d'ar vuez...

(https//www.diocese-quimper.fr/fr/aviel-sant-vaze?start=7, last accessed 10.10.2019) Because strait is the gate, and narrow the way which lead for living ones...

14. Cf. also modern French sens 'direction' and sens 'sense', now seen as homonymic, but actually derived from the same Latin word. The meaning of 'direction' is assumed to have appeared through the semantic transition 'understanding' => 'mode of action' => 'direction' (see Hatzfeld and Darmesteter 1964, II: 2028), yet, in my opinion, their conclusion on the nature of this semantic shift is far from certain. 
HOW TO SAY 'ROAD’ IN IRISH

Mark 10.46: D'ar mare m'edo Jezuz o kuitaad Kêr gand e ziskibien hag eur boblad mad a dud, e oa azezet, war bord an hent...

(https//www.diocese-quimper.fr/fr/aviel-sant-mark?start=10

[last accessed 10.10.2019]) $)^{15}$

And when went Jesus out of Jericho with his disciples, and there was people in a great number, he was sitting by the side of the road...

Cf. also Old Cornish hins 'way, road' and its composite derivative cam-hinsic (from cam 'crooked'), glossed as iniustus, literally 'crooked-wayed' (cf. Russian neputyoviy). It is presumably this word which acquired a broader range of meanings in the Brittonic languages, including the notions of 'way, travel, military campaign, mode of behaviour' (Geiriadur Prifysgol Cymru, s.v. hynt). The only English equivalent absent in The Welsh-English Dictionary is exactly 'road'. To my understanding, this means that in Modern Welsh, in contrast with Brittonic, derivatives of the Common Celtic * sentu- ceased to be basic (if they ever have been). This was caused by the fact that Middle Welsh employed the borrowing from OEng. ford (which partly retained the earlier, broader meaning of 'passage'): the word ffordd acquired the basic meaning of 'road', later developing additional meanings such as 'motion, run, travel, journey'. In the test examples from the New Testament already cited, the word ffordd is used in both the literal and the metaphorical meaning ("sitting by the road side," Mark 10: 46; "narrow road / way," Matthew 7: 14).

Oblegid cyfyng yw'r porth, achul yw'r ffordd, sydd yn arwain I'r bywyd...

(see Y Beibl Cyserg-Lân 1968: 927)

Because strait is the gate, narrow is the road which leads for life...

Surprisingly, a reverse semantic transition is realised - from 'road' (as a locus of motion) to 'way' (as mode and/or target of motion).

Notably, in Welsh, the word ffordd is seen as "basic" only within northern dialects, while in southern dialects it is replaced by heol. "Both speakers and dictionaries note a considerable degree of variability of this word between dialects: according to the map, there are northern ffordd, southern heol, Anglesey lôn" (Parina 2009: 145; cf. similar data in Elsie 1979: 35). The Welsh heol, hewl has quite a broad

15. As Gary German kindly pointed out to me, in Breton, eeun gant e hent (lit. 'straight with his road') is an idiom meaning "honest". Another example where Breton hent 'road' is used in the meaning of 'way' is the following expression: Kerz kuit deus ma hent! ('Get out of my road (=way)!') Similarly, dialect speakers in the northwest Midlands say "get out of my road" (rather than "get out of my way") or "anyroad" (rather than "anyway"). 
range of meanings - 'way, road, motion, travel, wandering' (Geiriadur Prifysgol Cymru, s.v.) - and is traditionally linked to the Old Irish séol 'sail, sailing, motion, way', believed to be an early borrowing from Germanic (for details, see Schrijver 1995: 357; an alternative etymology is proposed by Dočkalová and Blažek 2011: 312). The relation between 'sail' and 'road' seems to represent a more complex course of semantic derivation: 'sail' => 'sailing' => 'journey' => 'road, way'. In other words, this derivation can be interpreted as a more elaborate version of Model 1.

Old Irish sét, to my knowledge, does not bear the direct meaning of 'road', yet retains the original meaning of 'movement, transition'. So it is rather closer to 'way'. It has a curious derivative noun sétig (from * sent-ik-i-, see De Bernardo Stempel 1999: 80) - 'wife, spouse', literally 'companion'. In Middle Irish, the verb sétaigid 'he/she travels' derives from the same stem. In the Old Irish glosses, a metaphoric usage of sét appears, for 'way, mode of action, life trajectory':

... quae sunt in Christo Iesu .i. is i crist ataat in sét sin

... it is in Christ those ways are

(Stokes and Strachan 1975: 551)

The same is true of early Irish lyrics. Cf. for instance, an $8^{\text {th }}$-century poem:

Sét no tíag / téiti Christ...

The path I walk / Christ walks it...

(Carney 1971: 27-8)

There are also examples from the $9^{\text {th }}$-century Irish monastic poetry where this word clearly conveys the idea of motion:

Mét mo boithe-bec nád bec-/ baile setae sognath... Mennután díamair desruid / día mbi selb sétrois

The size of my hut - small yet not small - a homestead with familiar path.

Little hidden humble abode, with path-filled forest for estate...

(Murphy 1998: 10)

In the last example, the combination sét + ross 'forest' conveys not so much the idea of paths in the forest as the picture of the forest known backward and forward, which is a domesticated and familiar space for the hermit. There is another poem where the word sét conveys the idea of 'way' or 'motion' rather than 'road' itself. 
This is a protective charm attributed to St Columba (on linguistic grounds, it is dated to c.900 AD):

M'aenarān dam isa sliab / — a rī grian rob soraid sét;

I go alone toward the mountain, O King of suns let the way be smooth

(Borsje 2015: 22)

Cf. a further example provided by Middle Irish poetry in the marginalia, where the figurative, metaphoric sense is clear, taken from the Lebor Brecc, fol. 223:

Mór in bét! Immad sliged ocus sét

Dar lebaid na sruthi soer, tar nar'chóir acht óen do chét.

Great is the pity! Many are the ways and roads

Across the bed of the noble rivers, across which but one in a hundred is right

(Meyer 1899: 225)

One can tentatively conclude - without over-generalisation, just to outline an apparent tendency in contextual usage - that the word sét in Goidelic signifies a journey or transition, referring to the speaker rather than the listener, and conveys rather the idea of spiritual quest and mental, rather than physical, wandering. At any rate, even if a given text describes a seemingly physical journey, the word, firstly, as a rule, refers to the author and his own travelling; secondly, again, its subtext suggests travelling along the "road of life". Cf. the $9^{\text {th }}$-century lorica for the journey, ascribed to Máel Ísu Ua Brolchán:

Rop soraid in sét-sa, rop sét lessa im lámaib, / Crist credal fri demnaib, fri arniaib, fri áraib! May this journey be expeditious, may it be a journey of profit in my hands! Holy Christ against demons, against weapons, against slaughters!

(Meyer 2012: 112)

Rather than actual motion, a mental kind of motion is also implied by a verbal back-formation from the same stem, sétaigid, in a $10^{\text {th }}$ century poem "On the Flightiness of Thought":

Tresna salmu sétaigid / for Conair nád cóir

During the psalms they wander on a path that is not right

(Murphy 1998: 40) 
Cf., however, another example from a Late Middle Irish saga Aislinge Meic Con Glinne:

Do-chummlai i cend sétta 7 imdechta dar crích Connacht

He sets off after path and wandering through Connacht...

(Jackson 1990: 4)

As we have seen, unlike Brittonic languages, Goidelic tends to preserve the archaic notion of movement or transition, failing to shape the specialised concept of 'road'. For the word sét, the metonymic shift from 'motion' to 'locus of motion' seems to be attested (putatively) only in the compound drochet 'bridge' $<{ }^{*} d r u k^{-}{ }^{*}{ }^{*} \bar{e}-$, in which the meaning of the first part is open to debate: it may derive either from *druko'tree, wood', or from *dhregh- 'to run, to hurry', from which the Old Irish droch 'wheel' is derived (LEIA-D: 199; Hamp 1982: 144-6; De Bernardo Stempel 1999: 45).

The modern form séad belongs rather to the lofty style and means "a track, path or course (oft. fig.), a journey, a wandering" (Dinneen 1927: 998).

So, as we have seen, in Goidelic, unlike Brittonic, the Common Celtic * sentuhas never developed (or has lost?) the basic meaning of 'road'. For 'road', the languages of this group would choose another model of semantic derivation.

Somewhat close to sét may be OIr. conar, f. 'path, journey, expedition, route; way, manner', still present in the language today. ${ }^{16}$ Its etymology is unclear, so one cannot securely place it within Model 1 ('road' as transition). Moreover, as Dočkalová and Blažek (2011: 311) point out:

Pedersen ${ }^{17}$ considered the semantic source "path of the dogs", analogically to bóthar "path", literally "path of livestock" [that is, after Model 3, see below-T. M.]. If we take into account that the most common motivation for names of "paths" and "footpath" is a verb denoting some movement, it is possible to consider a similar source

They suggest that Old Irish conar is cognate with Greek konarōs 'active, strong, huge, rash'; that is, their idea seems to suggest nominalisation of a verbal stem with a generic meaning of 'hurry, rush, head off'. This hypothesis seems to be theoretically prospective, yet not sufficiently evidence-based.

The semantics of conar is of particular interest, since it is apparently context-dependent. Thus, in monastic lyrics, which are mostly introspective and rich in metaphors, conar, as I pointed out above, is rather synonymic with sét, that is, bearing the meaning of 'path, way, journey'. More importantly, this word stands

16. Cf. the title of an Old Irish legal tract Cóic conara fuigil 'Five ways of bringing action', and of a modern bilingual (English-Irish) piece of creative writing: A path home-Conair siar (Bannister 2018).

17. See Pedersen 1909-13, II: 51. 
for motion or journey as such, without localising it in any way or placing within the island's actual geography. For instance:

Cross cuirp Christ is Muire dar coimét for conair.

May the cross of Christ's body and Mary guard us on the road.

(Meyer 1912: 112)

Or:

Cia dú do fhir conaire / Cuingidh comairge for sét...

Though it be proper for a traveller (lit. 'man of road, path') to seek protection on a journey...

(Carney 1940: 109, 111)

Similarly to the English way (as well as Russian put'), conar acquires the meaning of 'way, manner':

Ní conair do degmnai dil | Suibne sunn ar slicht imnid

No path for a lovely lady | is that of Suibne here on the track of trouble.

(Murphy 1998: 120).

At the same time, according to the data from eDIL, in prepositional constructions ( $i$ cenn conaire, ar conair, for conair), this word receives the meaning 'on the way'. Thus, it does not refer to the actual locus of movement.

Stranger, though, is its characterisation as a 'generic term' given by Charles Doherty in The Terminology of Roads in Early Ireland. Examples cited by him seem, on the one hand, to refute the idea that the word conar stood for 'locus of movement', but to my knowledge, in legal tracts, it specifically refers to various kinds of trodden, cut or paved roads with special functions. Cf. conar chúan 'well-trodden way', conar coitchend 'public way, owned in common' (Doherty 2015: 28). Perhaps the main argument for categorising this word as a generic term for 'road' could be the entry from the so-called Cormac's Glossary (not cited by Doherty):

Atät tra ilanmand for na conaraib

There are many words for the roads

(Meyer 1913: 96) 
Cormac goes on to provide a list of six different words, some of which mean mostly 'road' as such (as a locus of movement, see below) and only one bears the meaning of 'way' or 'journey', and it is exactly sét discussed above.

\subsection{Model 2}

Model 2 is, properly speaking, also based on a metonymic transfer, yet not of the type 'action' => 'locus of action', but rather of the type 'action' => 'result of action', specifically, as a rule, bearing extra morphological components: 'to make' => 'a made object'. ${ }^{18}$ One may speculate, judging by the tentative historical and sociological evidence, that this type of derivation of words for 'road' is of later origin, since it implies a certain evolutionary level of civilisation and, moreover, state institutions (the reader may think of road-building as the signature of the expanding Roman empire).

The model 'road' seen as 'product of processing in some way a certain part of land' is quite widespread in IE languages. In the first place, of course, there is Russian doroga, derived from the reconstructed proto-Slavonic verb *dzrgati 'to drag, to tug, to pull' (see Serbo-Croatian draga, Czech dráha, Polish droga, Ukrainian doróha 'way, route'). Some Slavonic languages use the same stem and, most importantly, the same idea ('an area cleared from grass and bushes') for designations of wastelands and passages for grazing livestock (see ЭССЯ 1978: 75, 221, and also Dočkalová and Blažek 2011: 301).

In a number of other Slavonic languages, Model 2 employs the verbal stem *céstiti 'to clear' (cf. Czech and Polish cesta 'road', ЭССЯ 1976: 188). The Polish word is tentatively reconstructed as a loanword from Czech (Dočkalová and Blažek 2011: 301).

A similar concept of a 'human-made road' is present in Romance languages, most of which use words descending from Lat. (via) strāta 'paved road'. The examples that come to mind are It. strada, Rom. strada (more precisely, 'street'), Port. estrada 'street, road'; cf. also a very early Latin loanword in Germanic, dating from about the $4^{\text {th }}-5^{\text {th }}$ centuries, sträza 'road, paved road, street', from which many extant Germanic languages got their words for 'street' (Kluge 1957: 756). Cf. also Latin (via) rupta 'road that is broken through', from the verb rumpere 'to break' > French route 'road' (whether this word belongs to the basic list is still open to debate, given that it competes with the word chemin).

The same model produced the ON. braut 'road', from the verb brjóta 'to break' (Buck 1949: 718; De Vries 1962: 55; Toporova 2018: 18-26).

18. Dočkalová and Blažek (2011: 330) propose the same idea (denoting 'road' by construction method), yet in a different wording: "semantic motivation based on landscaping"; that is, the authors assume that the semantic core refers to cleared forests, tunnels bored in rock, corduroyed bogs, etc. 


\subsection{Model 2 in Celtic}

In Goidelic, this model is employed in the designation of 'road' that had certainly been basic in Old and Middle Irish: slige (gen. sliged), from the verb sligid 'breaks, strikes' (LEIA-S: 133). Morphologically, it is a passive participle derived from a transitive verb stem, which is evidenced by the suffix $-d / ð /<-t / \theta /$, subject to vocalisation in the unstressed syllable as early as in Old Irish (McCone 1994: 141, 167; on derivation, see McCone 1995). The Old Irish word for 'road' means, therefore, 'glade', a space cleared for passage ${ }^{19}$ (on the use of the term in law tracts, see Kelly 1997: 538). As Mallory writes, in his book In Search of the Irish Dreamtime:

The slige 'highway', defined in the law texts as a road wide enough for two chariots, is the commonest term employed in the Ulster tales. Initially indicating the act of felling trees to clear a way, its etymological origins are occasionally reflected in the tales. For example, Medb digs up a road through the Cooley mountains so that it might serve as a monument to her raid.

(Mallory 2016: 223)

The editors of The Dictionary of the Irish Language (DIL) suggest that as early as in Middle Irish this word acquired an additional metonymic meaning of 'journey, voyage': 'road' => 'the state of being on the way'. For instance:

ar a shlighidh go Baile Attha Cliath fuair bás

(DIL, s.v. slige (b) = Cameron 1892-4, II: 166.14, 'The Book of Clanranald')

on his way to Dublin he died (= 'on a journey to Dublin')

Cf. another example from DIL: cethre sligthe imdénta "four methods of proof" (cited from the so-called O'Davoren's Glossary, completed about the mid- $16^{\text {th }}$ century; see Stokes 1862: lix).

Patrick S. Dinneen's Irish-English Dictionary that represented the Irish language of the late $19^{\text {th }}$ to early $20^{\text {th }}$ century provides multiple English equivalents of the word slighe, and idioms associated with it. To my understanding, by that time, the modern Irish slighe had lost the literal meaning of 'road' and acquired the meanings of "mode, method, manner or habit" (Dinneen 1927: 1055-6). The Irish-English Dictionary by Niall Ó Dónaill (1977) attests to it now in the form sli, with the prevailing meanings that can be viewed as rather figurative - 'right, normal course of action; means, method'. However, the meanings 'distance, journey' and 'passage' are also present. With this in mind, one cannot but cite a popular Irish euphemism

19. On "five great roads" of Ireland, see: O’Lochlainn 1940; Bondarenko 2014. 
Tá siad ar shli na fírinne "they are gone to their eternal reward" (Ó Dónaill 1977: 1111) that can be literally translated "they are on the road of righteousness" in the meaning 'they are dead'.

In Scottish Gaelic, according to MacLennan's Dictionary, the word slighe has lost any relation to 'road' in a literal sense and become 'way, journey, manner' (MacLennan 1979: 305). Meanwhile, consulting the Scottish Gaelic text corpora shows that this is not quite the case. ${ }^{20}$

Curiously, however, the 1992 Scottish Gaelic translation of the New Testament has slighe in Mark 10:46:21

bha Bartimeus an dall, mac Thimèuis, na shuidhe ri taobh na slighe, ag iarraidh dèirce

Bartimeus, the blind, the son of Timeus, was sitting by the road, begging

The 2017 translation employs a totally different word, here used for the idea of 'locus of motion':22

bha Bartimèus, dèirceach dall, na shuidhe ri taobh an rathaid

Bartimeus, the blind beggar, was sitting by the road

Modern Scottish Gaelic rathad is probably derived from Old Irish ramut, whose etymology is unclear (see LEIA-R,S: 6) and may be cognate with Old Irish rait/roit 'road' of no clearer etymology. This word is not common, but attested as early as in Old Irish in the figurative meaning of 'way, mode of action, manner', cf. e.g. rámat firinne (eDIL s.v. rámat) 'right, proper behaviour'. Thus, it undergoes the same semantic evolution, from 'locus of motion' to 'way of motion' and then to a generic meaning of 'motion, manner, mode, etc.' Unfortunately, the lack of an etymon for this word does not allow us to trace its semantic evolution in its entirety.

The lexeme features in the saga Airne Fingein about a woman from the Otherworld who tells the king about miracles that happen on the Samhain night. Among such wonders, five main roads of Ireland (cóic prímróit hÉrenn) are mentioned. Curiously, these roads are presented as not having been created immediately on that night.

20. See DASG - https://dasg.ac.uk [accessed 10.10.2019]).

21. The example is cited from the on-line resource https://bibles.org/bible/22b6f0cee3f69bfd-01/ MRK.10? parallels=22b6f0cee3f69bfd-01\&passageId=MRK.10.1-MRK.10.52\&q=Marcus\%2010 [accessed 10.10.2019]).

22. Cited from https://scottishbiblesociety.org/2019/04/gaelicntprint/ [accessed 10.10.2019]. 
One can suggest that, in this particular case, the compiler implied that the roads had been constructed (or, rather, laid out) across the boglands in the mythological age. Likewise, causeways across the boglands have been perceived as constructed by the supernatural race of the sidhe, also perceived as the mound-dwellers. As the saga Tochmarc Etaine relates, the king of Tara, Eochaid Airem, commanded the sidhe to pave the bog in a single night. According to Manco, "no wonder that Eochaid Airem's causeway was seen as imaginary - until, that is, an impressive timber causeway was uncovered in Corlea. It was built in $148 \mathrm{BC}$ across the boglands of Longford, close to the River Shannon" (Manco 2015: 20).

What then was the Irish name for this type of road? And what semantic motivation underlay it? The saga in question describes the construction of such a road in the following manner:

Dogensat uile oendumae dia n-édaigib, 7 luid Midir forsin dumae sin. In fhidbadh cona bun 7 cona fremaib, is ed sin doberdis a n-ichtar an tochair. ... Iar sin doberar uir 7 grian 7 clocha forsin monai ... Ni biad isin bith tochar bud ferr mina beithi ocá deiscin.

They all made one mound of their clothes, and Midir went up on that mound. Into the bottom of the causeway they kept putting a forest with its trunks and its roots.... After that, clay and gravel and stones are placed upon the bog. ... There had been no better causeway in the world, had not a watch been set on them.

(Bergin and Best 1938: 178-9).

What is essential for us, in this case, is the semantic motivation of the word for a road over a bog. The word tóchar is a verbal noun from the Old Irish verb do-cuirethar (Middle Irish tochraid) 'puts, deposits, places'. Indeed, this meaning corresponds well with the process of corduroying described in the saga; therefore, tóchar unmistakably fits into Model 2 (the word for 'road' derived from the method of construction). However, unlike slige, the word tóchar, to my understanding, had never been mentioned on the 'basic' list, or, simply put, was not very widespread, which allowed it to retain the meaning of 'causeway' until now.

Words of more common usage, as we have seen, tend to extend their range of meanings and therefore lose their semantic motivation. Yet, the extension of metaphoric usage inevitably blurs the semantic interpretation of 'locus of motion' itself. Thus, one has to expect the emergence of a new word with a generic meaning of 'road'. Let us move on to Model 3.

\subsection{Model 3}

The very emergence of new models after which the words for 'road' are formed is caused, to my understanding, by the fact that older words tend to come to resemble 
dead metaphors. Thus, the abundance of words for paths, roads and passages of different types and functions makes the language try to specify which of them is the 'main road'. Thus, for instance, in Middle English, the compound heigh-weye 'main

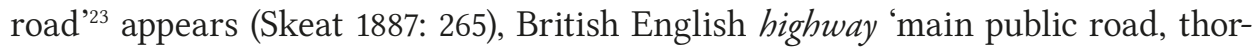
oughfare' (cf. French grande-route, Rus. bolshak 'big road').

Model 3 is most typically based upon specification of the pre-existing road by the preferential type of use. ${ }^{24}$ Somewhat more challenging are the words derived from verbal stems with the meaning of 'motion' (that is, resembling Model 1), yet it is motion of a specific type. For relatively archaic cultures, it is not always easy to distinguish between 1 and 3. Thus, French chemin (Spanish camino) is derived from Latin camminus, which, in its turn, is a loanword from Gaulish: its reconstructed form is *ammano-, also attested in the Celtiberian place-name Kamanom. The putative verbal stem is *cing- 'to walk' ( ${ }^{*}$ cang-sman-o-, which also gave rise to Old Irish cingid 'proceeds', and its verbal noun céimm 'step'; see more in Delamarre 2003: 100).

Indeed, the most obvious example of Model 3 is English road derived from OE $r \bar{a} d$, from the verb rìdan 'to ride' (on horseback or in a chariot) (Skeat 1887: 513; LIV 503). Cf. a nearly identical semantic model in Modern Greek $\delta \rho$ ó $\varsigma$ ' 'road' derived from the designation of running, horseracing, chariot driving (that is, from its preferential ways of use). The Greek word would later give rise to a number of Balkan area loanwords, such as Bulgarian drum 'big road, thoroughfare', Albanian drum 'path, passage', Romanian drumul 'passage, way'. One of the Dutch words for 'road', spoor, is derived from Proto-Germanic *spere 'to walk, to tread' (just as German Spur 'track, trail'). That is, 'road' is again identified by the preferential means of moving along. However, most other cases of this sort present no such problem, because the new word for 'road' is also linked with this preferential style of moving.

\subsection{Model 3 in Celtic}

This type of derivation may be attributed to Gaulish mantalon, attested mostly in place names and originating from PIE *men- 'to tread on, to trample on' (IEW 726; Delamarre 2003: 216). However, this case is unclear because the continental evidence may indicate not a 'road for walking' but a 'field for assemblies on foot', or it could mean both (Sims-Williams 2006: 90-1).

The same model might have been employed in Irish cosán 'little footpath'. Dočkalová and Blažek (2011: 311) propose its derivation from the Old Irish word for 'foot' (coss); however, this explanation is akin to folk etymology.

23. It is exactly this word that King James Bible employs in Mark 10:46 (sat by the highway side).

24. The paper cited above (Dočkalová and Blažek 2011) has a representative sampling of this type derivation, but does not distinguish between the generic idea of 'motion' and specific kinds such as running, walking, riding, etc. To me, this distinction is important, since it indicates the diachronic process within basic designations of 'road' and explains their shifts. 
Vendryes proposed that Modern Irish cosán derived from Old Irish casán, which in its turn came from the adjective cas 'curly, elaborate' (LEIA-C: 45). Presumably, a narrow passage or path is normally perceived as winding rather than straight (which is indeed a typical idea of 'path'; $c f$. a regular Russian collocation - tropinka $v$ 'jotsia 'the path is winding', while doroga normally 'goes' or 'leads straight ahead'). Naturally, this word does not have the 'basic' meaning of 'road'.

The designation of 'road' by identifying its preferential subject of motion, which would receive the 'basic' status, seems to have formed already in the Old Irish period. This is the word bóthar <*bou-itro- 'passage for cattle' (LEIA-B: 74). It is first attested in the already mentioned $9^{\text {th }}$ century Cormac's Glossary. The compiler of the glossary explains the word accordingly:

Bōthar, talla dā boin fair .i. alanāi for fot, alaile fortarrsnae, ara talla a llöigu 7 a ngamna ina farad, ar mad ina ndiaid beit iurthass in bö bias dia èis

A bóthar, two cows fit upon it, i.e. one lengthwise, the other athwart, for their calves or their yearlings fit on it along with them, but if they [the calves] were behind them [the cows], the cow that followed would gore.

(Meyer 1913: 96)

In Middle Irish and later, the word is only attested with the meaning of 'road'. I refer to 'control' examples from the New Testament in a modern translation:

dall a bhiodh ag iarraidh déirce, ina shui ar ghrua an bhóthair

lit. a blind man who was begging sat by the side of the road

(Mark 10:46, cit. from Ó Cuinn 1970: 110);

Mar is caol cung an geata agus is deacair duamhar an bealach ${ }^{25}$ a théas chun na beatha

lit.: 'For narrow and strait is the gate, and hard and tough is the way of coming to life'

(Matthew 7:14, cit. from Ó Cuinn 1970: 17)

The translator's introduction of alliterative synonymic epithets may be of special interest; however, what matters to me presently is the fact that the word bothar

25. Modern Irish bealach (OI belach) has no meaning 'road' as a locus of motion, but rather represents the range of meanings connected with 'way' or 'meaning of action'. Its etymology is obscure (see Dočkalová and Blažek 2011: 309). 
apparently has no metaphoric meaning for him, being simply 'road' as a space of motion. But, reduced to the mere 'road' in Middle Irish, the word bothar would then automatically develop the traditional metaphor and merge with the 'road' as 'way, manner'. Thus, Ó Dónaill's Irish-English Dictionary cites the following expression: “Tá bóithre deasa aige, he has nice ways with him” (Ó Dónaill 1977: 128).

\subsection{Conclusion}

The 'road' metaphors, which I have reviewed only superficially here, are outside the scope of my research, although the very presence of abundant metaphors is conceivably one of the reasons why the word has a relatively unstable position in the 'basic' list (for IE languages, the stability index is 0.28 ). Another reason is extra-linguistic: sociocultural development implies the emergence of new words for new things and ideas, and the old 'road as a passage' becomes opposed to the 'paved road'. This is the trend of semantic evolution that I am seeking to describe by identifying the three models of word derivation for the specific denotation of 'road' in their historical and social context. To my mind, this line of thought seems quite logical; however, why some languages, such as Serbian or Breton, retain the archaic words is a matter still open to debate. It is worth remembering that the words in question were taken by me from the 'basic' word list, that is, the list of notion-based words or items that steadily resist change, or rather accept it at a strictly ranked, slowed pace.

\section{Moscow State University — Institute of Linguistics RAS (Moscow)}

\section{Abbreviations}

IEW - Pokorny, J., 1959, Indogermanisches etymologisches Wörterbuch, Bern, Munich: Francke.

LEIA - Lexique étymologique de l'irlandais ancien de J. Vendryes (B-ed. by E. Bachellery and P.-Y. Lambert, Paris: CNRS, 1980; R, S-ed. by E. Bachellery, Paris: CNRS, 1974; C - ed. by E. Bachellery and P.-Y. Lambert, Paris: CNRS, 1987).

LIV - Lexicon der indogermanischen Verben, ed. H. Rix et al., Wiesbaden: Reichert, 2000 (1998).

Y Beibl Cyserg-Lan - Y Beibl Cysegr-Lân. Sefyr Hen Destament a'r Newydd, 1588, London: Christopher Barker (Repr. 1968).

ЭССЯ - Etymological Dictionary of Slavonic Languages [Этимологический словарь славянских языков] Moscow: Nauka (vol. 3-1976, vol. 5-1978). 


\section{References}

Apresian, J. D., 1995, Selected works [Избранные труды], vol. I, Lexical semantics [Лексическая семантика], Moscow: Jazyki slavianskoj kul'tury.

Bannister, G., 2018, A Path home - Conair siar. Zen koans in English and Irish, Dublin: New Island Books.

Benveniste, E., 1954, 'Problèmes sémantique de la reconstruction', Word 10, 251-264. Benveniste, E., 1973, Problems in General Linguistics. Miami: University of Miami Press. Bergin, O., \& Best, R. I., eds., 1938, 'Tochmarc Étaine’, Ériu 12, 137-196.

Blažek, V., 2007, 'From August Schleicher to Sergei Starostin: On the Development of the Tree-diagram Models of the Indo-European Languages', Journal of IndoEuropean Studies 35 (1-2), 82-110.

Blažek, V., 2010, Indo-European "Smith" and his Divine Colleagues, Washington, DC: Institute for the Study of Man.

Blažek, V., \& Novotná, P., 2006, 'On Application of Glottochronology for Celtic Languages', Linguistica Brunensia 54, 71-100.

Bondarenko, G., 2014, 'Roads and Knowledge in Togail Bruidne Da Derda', in: G. Bondarenko, Studies in Irish Mythology, Berlin: Curach Bhán Publications, 155-174. Borsje, J., 2015, 'Celtic Spells and Counterspells', in: K. Ritari \& A. Bergholm, eds., Understanding Celtic religion: Revisiting the pagan past. New approaches to Celtic religion and mythology, Cardiff: University of Wales Press, 9-50.

Buck, C., 1949, A Dictionary of Selected Synonyms in the Principal Indo-European Languages, Chicago: University of Chicago.

Cameron, A., 1892-4, Reliquiae Celticae, 2 vols. Inverness: Northern Counties Newspaper and Printing and Publishing Company.

Carney, J., ed., 1940, ‘M’aenarán dam isa sliab’, Éigse 2, 107-113.

Carney, J., ed., 1971, 'Three Old Irish Accentual Poems', Ériu 22, 23-80.

De Bernardo Stempel, P., 1999, Nominale Wortbildung des Älteren Irischen. Stammbildung und Derivation, Tübingen: Max Niemeyer.

De Hoz, J., 2005, 'Ptolemy and the Linguistic History of the Narbonensis', in: J. De Hoz, E. R. Luján, \& P. Sims-Williams P., eds., New Approaches to Celtic place-names in Ptolemy's Geography, Madrid: Ediciones Clásicas, 173-188.

Delamarre, X., 2003, Dictionnaire de la langue Gauloise. Un approche linguistique du vieux-Celtique continental, Paris: Éditions Errance.

Delamarre, X., 2005, 'Les noms du compagnon en Gaulois', Studia Celtica Fennica 2, 47-52. Dinneen, P. S., 1927, Foclóir Gaedhilge agus Béarla —Irish-English Dictionary, Dublin: Irish Texts Society.

Derksen, R., 2008, Etymological Dictionary of the Slavic Inherited Lexicon, LeidenBoston: Brill. 
De Vaan, M., 2008, Etymological Dictionary of Latin and the other Italic Languages, Leiden-Boston: Brill.

De Vries, J., 1962, Altnordisches etymologisches Wörterbuch, Leiden: Brill.

Dočkalová, L., \& Blažek, V., 2011, 'On Indo-European Roads', The Journal of IndoEuropean Studies 39 (3-4), 299-341.

Doherty, C., 2015. 'A road well travelled: the Terminology of Roads in Early Ireland', in: E. Purcell, P. MacCotter, J. Nythan \& J. Sheehan, eds., Clerics, Kings and Vikings. Essays on medieval Ireland in honour of Donnchad Ó Corráin, Dublin: Four Courts, 21-30. Dolgopolsky, A., 2000, 'Sources of Linguistic Chronology', in: C. Renfrew, A. McMahon \& L. Trask, eds., Time Depth in Historical Linguistics, Cambridge: McDonald Institute for Archaeological Research, 401-409.

Elsie, R. W., 1979, The Position of Brittonic. A Synchronic and Diachronic Analysis of Genetic Relationships in the Basic Vocabulary of Brittonic Celtic, Bonn: Rheinische Friedrich-Wilhelms-Universität.

Ernout, A., \& Meillet, A., 1939, Dictionnaire étymologique de la langue latine: histoire des mots, Paris: Klincksieck.

Falileyev, A., 2010, Dictionary of Continental Celtic Place-Names, Aberystwyth: CMCS. Fowkes, R. A., 1971, 'Glottochronology and Brythonic?', Studia Celtica 6, 175-88. Geiriadur Prifysgol Cymru: A Dictionary of the Welsh Language, Cardiff: Gwasg Prifysgol Cymru, 1951- (available at http://geiriadur.ac.uk/gpc/gpc.html)

Greimas, A. J., 1968, Dictionnaire de l'ancien Français jusqu'au milieu du XIVe siècle, Paris: Librairie Larousse.

Hamp, E. P., 1982, ‘*-og- in British Celtic and Notes on bro-', Études Celtiques 19, 143-9. Hatzfeld, A., \& Darmesteter, A., 1964, Dictionnaire general de la langue Française vols. 1-2, Paris: Delgrave.

Henderson, I., 1967, The Picts, London: Thagmes \& Hudson.

Jackson, K. H., ed., 1990, Aislinge Meic Con Glinne, Dublin: DIAS.

Kassian, A., Starostin, G., Dybo, A., \& Chernov, V., 2010, 'The Swadesh wordlist: An attempt at semantic specification', Journal of Language Relationship: International Scientific Periodical 4, 46-89.

Kelly, F., 1997, Early Irish Farming, Dublin: DIAS.

Kluge, F., 1957, Etymologisches Wörterbuch der Deutschen Sprache, Berlin: de Gruyter. Kroonen, G., 2013, Etymological Dictionary of Proto-Germanic, Leiden-Boston: Brill. Laing, L. \& J., 1993, The Picts and the Scots, Stroud: Sutton Publishing.

MacLennan, M., 1979, A Pronouncing and Etymological Dictionary of the Gaelic Language. Gaelic-English, English-Gaelic, Aberdeen: ACAIR and Aberdeen University Press.

Mallory, J. P., 2013 The Origins of the Irish, London: Thames \& Hudson.

Mallory, J. P., 2016, In Search of the Irish Dreamtime. Archaeology \& Early Irish Literature, London: Thames \& Hudson. 
Mallory, J. P., \& Adams, D. Q., 1997, Encyclopedia of Indo-European Culture, London: Fitzroy Dearborn.

Mallory, J. P., \& Adams, D. Q., 2006, The Oxford Introduction to Proto-Indo-European and the Proto-Indo-European World, Oxford: Oxford University Press.

Manco, J., 2015, Blood of the Celts. The New Ancestral Story, London: Thames \& Hudson. Matasović, R., 2009, Etymological Dictionary of Proto-Celtic, Leiden: Brill.

McCone, K., 1994, 'An tSean-Ghaeilge agus a réamhstair', in: McCone, K., et al., eds., Stair na Gaeilge in ómós do Pádraig Ó Fiannachta, Maigh Nuad: An Sagart, 61-220.

McCone, K., 1995, 'OIr. Senchae, Senchaid and Preliminaries on Agent Noun Formation in Celtic', Ériu 46, 1-10.

Meyer, K., 1899, 'Irish Quatrains', Zeitschrift für celtische Philologie 2, 225.

Meyer, K., 1912, 'Four Religious Poems', Ériu 6, 112-116.

Meyer, K., ed., 1913, 'Sanas Cormaic An Old-Irish Glossary Compiled by Cormac úa Cuilennáin, King-bishop of Cashel in the Tenth Century', in: Bergin, O., Best, R. I., Meyer, K., \& J. G. O’Keeffe, eds., Anecdota from Irish Manuscripts, vol. 4, Halle: Max Niemeyer; Dublin: Hodges, Figgis \& Co., 1-128.

Murphy, G., ed., 1998, Early Irish Lyrics, Dublin: Four Courts Press (repr. 1956).

Ó Cuinn, C., ed., 1970, Tiomna Nua á dTiarna agus ár Slánaitheora Íosa Crtíost. An Canónach Oirmh, a d'aistrigh ón Revised Standard Version agus ón Gréigis, Dublin: Hibernian Bible Society.

Ó Dónaill, N., ed., 1977, Foclóir Gaeilge-Béarla. Baile Átha Cliath: Oifig an tSolatháir. O’Lochlainn, C., 1940, 'Roadways in Ancient Ireland', in: J. Ryan, ed., Féil-sgríbhinn Eóin Mhic Néill: Essay and Studies Presented to Professor Eoin MacNeill, Dublin: Three Candles, 465-474.

Orel, V., 2003, A Handbook of Germanic Etymology, Leiden: Brill.

Parina, E.A., 2009, 'The 100-word Core Vocabulary List for Modern Welsh' [Стословный список базовой лексики для современного валлийского языка], in: Mac Mathúna, S., Mikhailova, T., et al., eds., Proceedings of the Second International Colloquium of Societas Celto-Slavica (Moscow, 14-17 September 2006), Moscow: MaxPress, 139-146.

Pedersen, H., 1909-13, Vergleihende Grammatik der keltishen Sprachen, Bd. I-II, Göttingen: Vandenhoek \& Ruprecht.

Schrijver, P., 1991, The Reflexes of the PIE Laryngeals in Latin, Amsterdam/ Atlanta: Rodopi.

Schrijver, P., 1995, Studies in British Celtic Historical Phonology, Leiden: Brill.

Sims-Williams, P., 2006, Ancient Celtic Place-Names in Europe and Asia Minor, Oxford: Blackwell Publishing.

Skeat, W., 1887, An Etymological Dictionary of the English Language, Oxford: Clarendon Press. 
Smirnitskaja, O. A., 2008, 'Síð Béowulfes: Frames of Cultural Lexica in Old English Epic' [Síð Béowulfes: границы культурной лексики в древнеанглийском эпосе], in: O. A. Smitnitskaja, Selected works on Germanic Philology [Избранные статьи по германской филологии], Moscow: Max-Press, 161-170.

Starostin, S. A., 1999, 'Comparative-historical Linguistics and Lexicostatistics', in: Shevoroshkin, V., \& P. Sidwell, eds., Historical Linguistics \& Lexicostatistics, vol. 3, Melbourne: Association for the History of Language, 3-50.

Starostin, S. A., 2007, Труды по языкознанию [Works in Linguistics], Moscow: Jazyki Slavianskoj Kul'tury.

Starostin, G., 2010, 'Preliminary Lexicostatistics as a Basis for Language Classification: a New Approach', Journal of Language Relationship 3, 79-116.

Stokes, W., ed., 1862, Three Irish Glossaries, London-Edinburgh: Williams \& Norgate.

Stokes, W., \& Strachan, J., 1975, Thesaurus Palaeohibernicus. A Collection of Old Irish Glosses, Scholia, Prose and Verse, vols. I-II, Dublin: DIAS (repr. 1903).

Swadesh, M., 1952, 'Lexico-statistic Dating of Prehistoric Ethnic Contacts', Proceedings of American Philosophical Society 96, 452-463.

Swadesh, M., 1955, 'Towards Greater Accuracy in Lexicostatistic Dating', International Journal of American Linguistics 21, 121-137.

Toporova, T. V., 2018, The Epic Word: 'Road' and 'Way' in Elder Edda [Эпическое слово: обозначения дороги, пути в «Старшей Эдде»], Moscow: World Languages.

Traugott, E. C., \& Dasher, R. B., 2002, Regularity in Semantic Change, Cambridge: Cambridge University Press.

Watkins, C., 2011, The American Heritage of Indo-European Roots, 3rd ed., Boston/ New York: Houghton Mifflin Harcourt.

Wodtko, D., Irslinger, B., \& Schneider, C., 2008, Nomina im indogermanischen Lexicon, Heidelberg: Universitätsverlag Winter.

Zalizniak, A. A., Bulakh, M., Ganenkov, D., Gruntov, I., Maisak, T., \& Russo, M., 2012, 'The Catalogue of Semantic Shifts as a Database for Lexical Semantic Typology', Linguistics 50 (3), 633-669. 
